JOURNAL OF NURSING PRACTICE AND EDUCATION VOL. 01 NO. 02, JUNI 2021

DOI: $10.34305 /$ JNPE.V1I2.301
Ciptaan disebarluaskan di bawah Lisensi Creative Commons Atribusi-NonKomersialBerbagiSerupa 4.0 Internasional.

\title{
ANALISIS SELF-EFFICACY IBU DENGAN ANAK YANG SEDANG MENJALANI PENGOBATAN TUBERKULOSIS DI RUANG POLIKLINIK RS MITRA PLUMBON CIREBON
}

\author{
${ }^{1}$ Meliana Muchti Nuroctavia, ${ }^{1}$ Titin Supriatin, ${ }^{2}$ Cikwanto \\ ${ }^{1}$ STIKes Ahmad Dahlan Cirebon, ${ }^{2}$ Universitas Muhammadiyah Pringsewu \\ melyoctavia@gmail.com
}

\begin{abstract}
Abstrak
Tuberkulosis pada anak memiliki angka kematian dan angka kejadian yang cukup tinggi. TB Paru anak di perkirakan 9 juta kasus dimana 2 juta dari kasus tersebut mengalami kematian. Permasalahan Kesehatan yang saat ini dijadikan sebagai permasalah utama diantaranya adalah TB anak, karena Indonesia termasuk kedalam negara yang memiliki jumlah TB anak paling tinggi yakni 164/100.000 penduduk, dengan 100.000 jumlah kematian. TB yang dialami anak mencapai 28.418 atau 9\% dari seluruh jumlah kasus TB. TB di Indonesia pada tahun 2010 mencapai proporsi 9,4\%. Data menurut profil Kesehatan Indonesia tahun 2018 menggambarkan sebanyak 566.623 kasus TB anak yang telah ditemukan meningkat jumlahnya jika dibandingkan kasus pada tahun 2017 (446.732 kasus). Sedangkan menurut profil Kesehatan provinsi Jawa Barat (2017), di kabupaten Cirebon khususnya diperoleh data kasus TB anak sebanyak 180 (4,59\%). Prevalensi kasus pada TB anak (umur 0-14 tahun) mencapai 9\% dari seluruh populasi TB di Indonesia, di Jawa Barat sendiri berdasarkan kelompok kasus tuberkulosis pada tahun 2017 kasus TB anak mencapai 14,9 \% (Dinkes Jawa Barat, 2017). Di Cirebon jumlah TB anak mencapai 233 (5.12 \%) tahun 2017, dan di RS Mitra Plumbon menurut data dari tahun 2019-2020 tuberkulosis anak sebanyak 934 kasus. Ibu memiliki peranan yang sangat penting, karena ditangan ibu keberhasilan dari pengobatan TB anak, oleh karenanya selfefficacy ibu dengan anak penderita TB perlu dianalisa, karena tinggi dan rendahnya self efficacy ibu akan mempengaruhi dalam tinggi rendahnya tingkat stress, emosionalnya serta pola pikirnya. Tujuan penelitian adalah ingin mengetahui gambaran dari self-efficacy ibu yang menjalani program pengobatan TB di ruang anak Rumah Sakit Mitra Plumbon Cirebon. Dalam penelitian ini deskriptif analitik dengan pendekatan cross sectional merupakan metode yang digunakan, dengan seluruh jumlah ibu yang telah memenuhi persyaratan (total sampling) yang
\end{abstract}


JOURNAL OF NURSING PRACTICE AND EDUCATION VOL. 01 NO. 02, JUNI 2021

DOI: $10.34305 /$ JNPE.V1I2.301
Ciptaan disebarluaskan di bawah Lisensi Creative Commons Atribusi-NonKomersialBerbagiSerupa 4.0 Internasional.

dijadikan responden, didapat jumlah sebanyak 35. Didapatkan hasil yakni umur ibu pada rentang dewasa awal (94,3\%), Sebagian besar responden memiliki Pendidikan SMA (51,4\%), dan Sebagian tinggi pekerjaan ibu sebagai ibu rumah tangga (54,7\%). Gambaran self-efficacy ibu dengan TB anak di RS Mitra Plumbon Cirebon, diperoleh hasil bahwa tingkat self efficacy responden termasuk dalam kategori tinggi $(65,7 \%)$. Diharapkan dapat dikaji lebih dalam terkait keterlibatan ibu dan orang yang mengasuh anak dengan TB dalam menjalani pengobatan tuberkulosis pada anak.

Kata Kunci : self-efficacy, tuberkulosis

\section{PENDAHULUAN}

Tuberkulosis merupakan salah satu penyebab morbiditas dan mortalitas yang cukup tinggi pada anak. Setiap tahun diperkirakan 9 juta kasus TB paru dan 2 juta di antaranya meninggal. (Marlinae L at.all 2019). Hingga saat ini tuberculosis adalah permasalahan kesehatan yang utama. Indonesia termasuk dalam 5 negara dengan kasus tuberculosis yang paling banyak jumlahnya di dunia. Indonesia diperkirakan kasus TB Paru mencapai 164 per 100.000 penduduk, dengan 100.000 jumlah kematian Proporsi kasus TB anak di Indonesia yang ternotifikasi program TB adalah 330.812 kasus TB Paru, 28.418 diantaranya adalah kasus TB anak atau 9\% dari semua kasus TB. Tahun 2010 TB anak di antara semua kasus TB di Indonesia mencapai proporsi 9,4 \% kemudian menjadi 8,5\% tahun 2011 dan meningkat jumlahnya pada tahun 2015 yaitu mencapai jumlah 9\%. yang diperkirakan, dan pada tingkat kabupaten/ kota menunjukkan proporsi antara $1,2-17,3 \%$. (Kementrian Kesehatan RI, 2016)

Menurut profil Kesehatan Indonesia (2018), Angka kejadian tuberkulosis pada tahun 2018 ditemukan sebanyak 566.623 kasus, dibandingkan dengan kasus tuberkulosis yang ditemukan pada tahun 2017 mengalami peningkatan sebesar 446.732 kasus. Jumlah kasus tertinggi yang 
JOURNAL OF NURSING PRACTICE AND EDUCATION VOL. 01 NO. 02, JUNI 2021

DOI: $10.34305 /$ JNPE.V1I2.301
Ciptaan disebarluaskan di bawah Lisensi Creative Commons Atribusi-NonKomersialBerbagiSerupa 4.0 Internasional. dilaporkan terdapat di provinsi dengan jumlah penduduk yang besar yaitu Jawa Barat, Jawa Timur dan Jawa Tengah. Kasus tuberkulosis di tiga provinsi tersebut sebesar 44\% dari jumlah seluruh kasus tuberkulosis di Indonesia. Data dari profil Kesehatan Indonesia (2018) menyatakan bahwa terdapat 3 Provinsi dengan jumlah kasus TB tertinggi yang dilaporkan yaitu sebesar 44\% dari kasus TB yang ada. Ketiga provinsi tersebut yaitu Jawa Barat, Jawa Timur dan Jawa Tengah. Pada tahun 2017. Data tuberkulosis BTA positif tertinggi di Provinsi Jawa Barat mencapai 31.598 kasus .terdapat tiga Kabupaten/kota di Jawa Barat dengan kasus tuberkulosis yang tinggi yaitu di kota Sukabumi 400 kasus, kota Cirebon 396 kasus, dan kota Bandung 386 kasus. Selain itu menurut Kemenkes (2018) proporsi kasus tb anak per Provinsi tahun 2018 yaitu Jabar terdapat 15\% kasus TB anak. Prevalensi kasus tuberkulosis paru anak (umur 0-14 tahun) mencapai 9\% dari seluruh populasi tuberkulosis di Indonesia, di Jawa Barat sendiri berdasarkan kelompok kasus tuberkulosis pada tahun 2017 kasus tuberkulosis anak mencapai 14,9, (Dinas Kesehatan Provinsi Jawa Barat 2017). Berdasarkan data dari profil kesehatan Jawa Barat (2017) dipaparkan data jumlah penderita tuberkulosis paru di rumah sakit di seluruh Provinsi Jabar diantaranya yaitu RS Kabupaten Bogor sebanyak 1,124 (10.80\%), RS Kabupaten Sukabumi 357 (9.75\%), RS Kabupaten Bekasi $148 \quad$ (8.31\%), RS Kabupaten Karawang 99 (5.74), RS Kabupaten Garut 327 (10.65\%), RS Kabupaten Tasikmalaya 216 (9.85\%), RS Kabupaten Indramayu 183 (9.69\%), RS Kabupaten Subang 403 (44.46\%), RS Kabupaten Kuningan 117 (5.55\%), RS Kabupaten Cirebon 180 (4.59\%).

Menurut data profil Kesehatan Kabupaten Cirebon Tahun 2018 menyatakan bahwa di Kabupaten Cirebon jumlah TB anak mencapai 233 (5.12\%) tahun 2017, 
JOURNAL OF NURSING PRACTICE AND EDUCATION VOL. 01 NO. 02, JUNI 2021

DOI: $10.34305 /$ JNPE.V1I2.301

jumlah kasus TB anak menurut Dinkes Cirebon (2018) paling banyak terdapat di RSP Provinsi Jawa Barat 34 (3.59 \%) kasus, lalu disusul oleh Puskesmas Plumbon 19 $(18,81 \%)$ kasus, Puskesmas Sidamulya 16 (25.81 \%) kasus, Puskesmas Gunung jati 13 (20.00 \%) kasus, Puskesmas Astapada 10 (14.71\%) kasus, Puskesmas Beber 10 (14.08 \%) kasus.

Hasil rekapitulasi data dari RS Mitra Plumbon tahun 2019-2020, jumlah kasus TB anak yaitu sebanyak 934 Kasus.

Menurut Andi Purniawan (2019), menyatakan bahwa angka kejadian TB anak sangat rentan sekali yaitu pada golongan usia di bawah 6 tahun dan kelompok usia antara 7 hingga usia 14 tahun. Penelitian pada TB anak masih sangat rendah sekali, padahal jika hal ini tidak segera diatasi dapat menyebabkan kondisi kesehatan anak lebih buruk hingga menyebabkan kematian pada anak, (Andi Purniawan 2019).
Ciptaan disebarluaskan di bawah Lisensi Creative Commons Atribusi-NonKomersialBerbagiSerupa 4.0 Internasional.
Gejala klinis TB pada anak dapat berupa gejala sistemik/umum atau sesuai organ terkait. Gejala umum TB pada anak yang sering dijumpai adalah batuk persisten, berat badan turun atau gagal tumbuh, demam lama serta lesu dan tidak aktif. Gejala-gejala tersebut sering dianggap tidak khas karena juga dijumpai pada penyakit lain. Namun demikian sebenarnya gejala $\mathrm{TB}$ bersifat khas, yaitu menetap (lebih dari 2 minggu) walaupun sudah diberikan tetapi yang adekuat. Langkah awal pada alur diagnosis TB adalah pengambilan dan pemeriksaan sputum. Jika hasil pemeriksaan mikrobiologi (BTA/TCM, sesuai dengan fasilitas yang tersedia) positif, anak didiagnosis TB dan diberikan OAT. (Kemenkes RI 2016). Hal ini sesuai dengan pernyataan Nabilah at. All (2016) yang menyatakan bahwa dalam penanganan kasus TB perlu pengobatan yang teratur, baik pengobatan TB pada dewasa maupun anakanak, ketidakteraturan minum obat atau 
JOURNAL OF NURSING PRACTICE AND EDUCATION VOL. 01 NO. 02, JUNI 2021

DOI: $10.34305 /$ JNPE.V1I2.301

putus obat dapat menyebabkan resistensi bakter. Ibu memegang peranan yang sangat penting dalam kasus TB Paru pada anak, karena ibulah yang memberikan obat TB Paru pada kasus TB pada anak. (Nabilah, Ai Mardhiyah 2016)

Kepatuhan minum obat pada kasus tuberkulosis pada anak dibandingkan dengan dewasa dibutuhkan perawatan yang lebih intensif, terutama dukungan dan perhatian dari keluarga yaitu Ibu dan lingkungan rumah. Hal ini karena dalam pemberian obat tuberkulosis pada anak sangatlah dibutuhkan kesabaran, cara pemberian obat yang benar dan teratur bukanlah hal yang mudah khususnya pada anak-anak sering ditemukan penolakan, tidak mau diminum bahkan seringkali dimuntahkan, dan dapat menyebabkan aspirasi saat minum obat pada anak dan bayi. Pemberian obat dengan jangka waktu yang cukup lama ini merupakan tanggung jawab dari ibu bukan anak, olehkarenya dukungan
Ciptaan disebarluaskan di bawah Lisensi Creative Commons Atribusi-NonKomersialBerbagiSerupa 4.0 Internasional. dari lingkungan keluarga sangatlah dibutuhkan sekali. Keberhasilan kepatuhan minum obat pada tuberkulosis anak tergantung sekali pada orang yang sangat terdekat dan yang mengasuh penderita $\mathrm{Tb}$ anak. (Fernadiyanti. Dhanang Puspita. Dary 2018)

Self-efficacy individu sangatlah berpengaruh terhadap pola pikir dan perilaku seseorang, semangat dan motivasi serta tingkat emosional seseorang. Hal ini berkaitan erat dengan self-efficacy seorang ibu dengan anak yang mengalami tuberculosis. Dalam aktivitas seseorang selfefficacy sangatlah berpengaruh, besarnya upaya yang dilakukan dalam situasi apapun dan dalam waktu yang sedikit hingga butuh waktu yang sangat lama, dalam situasi tertentu di mana reaksi tingkat emosional seorang individu dalam mengantisipasi keterlibatan dirinya. Seseorang dapat berperilaku, berusaha berfikir dan juga dapat merasakan sesuatu dimana tingkat 
JOURNAL OF NURSING PRACTICE AND EDUCATION VOL. 01 NO. 02, JUNI 2021

DOI: $10.34305 /$ JNPE.V1I2.301

kepercayaan diri terhadap kemampuan yang dimiliki. Pada situasi seperti demikian sangatlah dibutuhkan rasa percaya diri dan merasa kompetensi dirinya cukup bisa dalam melakukan tugas dan tanggungjawab terhadap suatu hal. Pentingnya orang tua yang memiliki self-efficacy yang tinggi dalam merawat anaknya yang sedang mengalami tuberculosis. (Bandura 2009)

Berdasarkan data di atas, sehingga peneliti tertarik untuk melakukan analisis seberapa jauh self-efficacy pada ibu-ibu yang memiliki anak dengan TB paru dalam tanggungjawabnya menjalani pengobatan tuberculosis pada buah hatinya selama menjalani pengobatan TB di Poli anak Rumah Sakit Mitra Plumbon Cirebon.

\section{METHODE}

Penelitian merupakan suatu proses berkelanjutan dan tidak pernah berhenti melainkan selalu berkembang dan bergerak terus menerus. (Sucipto D 2020). Dalam penelitian ini menggunakan metode
Ciptaan disebarluaskan di bawah Lisensi Creative Commons Atribusi-NonKomersialBerbagiSerupa 4.0 Internasional. penelitian kuantitatif. Dimana penelitian tersebut menggunakan prosedur-prosedur statistik, fokus penelitian dan gejala yang tampak, dianalisis menggunakan teori secara objektif. (Donsu T 2016)

Menurut Putri (2016), dalam penelitian harus menentukan sejak awal, pada kesempatan ini peneliti menggunakan observasional, dimana jika peneliti melakukan observasional , maka perlu ditentukan apakah akan mengadakan pengamatan sewaktu (Cross sectional), yakni penelitian deskriptif dengan pendekatan cross sectional untuk menganalisis suatu fenomena dengan suatu penyebab. Tidak ada perlakukan yang diterapkan terhadap responden. (Putri 2016). Validitas menggambarkan kondisi instrument yang dapat digunakan dalam kondisi tertentu sesuai dengan kegunaannya. Sedangkan reliabilitas adalah gambaran stabilitas, konsistensi, dan ekuivalen instrumen dalam konteks yang diberikan 
JOURNAL OF NURSING PRACTICE AND EDUCATION VOL. 01 NO. 02, JUNI 2021

DOI: $10.34305 /$ JNPE.V1I2.301
Ciptaan disebarluaskan di bawah Lisensi Creative Commons Atribusi-NonKomersialBerbagiSerupa 4.0 Internasional.
(Putri, 2016). Instrumen yang digunakan dalam penelitian ini sebelumnya telah dilakukan uji validitas dan reliabilitas oleh peneliti sebelumnya, (Parlina 2018).

Populasi dan sampel penelitian telah memenuhi kriteria yang ditentukan peneliti, yaitu ibu dengan anak TB paru yang sedang menjalani pengobatan TB di Rumah Sakit Mitra Plumbon Cirebon, pada bulan
Desember 2020 hingga Februari 2021. Sedangkan sampel yang diambil adalah seluruh ibu dengan anak TB yang berobat ke RS Mitra Plumbon Cirebon dengan rentang waktu yang telah ditentukan dan telah memenuhi kriteria inklusi, dengan teknik sampling yaitu total sampling, dengan jumlah sebanyak 35 responden.

\section{HASIL}

\section{Karakteristik Responden}

Berdasarkan hasil pengolahan data karakteristik responden akan diuraikan sebagai berikut:

Tabel. 1. Distribusi Frekuensi Responden Umur, Berdasarkan Pendidikan, dan Pekerjaan $(\mathbf{n}=35)$

\begin{tabular}{lll}
\hline Variabel & Frekuensi & $\begin{array}{l}\text { Prosentase } \\
\text { (\%) }\end{array}$ \\
\hline Umur & & \\
Dewasa Awal & 33 & 94,3 \\
Dewasa Tengah & 2 & 5,7 \\
\hline Pendidikan & & \\
SMP & 7 & 20 \\
SMA & 18 & 51,4 \\
PT & 10 & 26,6 \\
\hline Pekerjaan & & \\
\hline Pedagang & 1 & 2,9 \\
PNS & 3 & 8,6 \\
Swasta & 12 & 34,3 \\
Ibu Rumah Tangga & 19 & 54,3 \\
\hline Total & 35 & $100 \%$ \\
\hline
\end{tabular}


JOURNAL OF NURSING PRACTICE AND EDUCATION VOL. 01 NO. 02, JUNI 2021

DOI: $10.34305 /$ JNPE.V1I2.301
Ciptaan disebarluaskan di bawah Lisensi Creative Commons Atribusi-NonKomersialBerbagiSerupa 4.0 Internasional.

Berdasarkan tabel 1 didapatkan hasil sebagian tinggi responden berusia dewasa awal yakni dengan jumlah 33 ibu usianya pada rentang 18 - 40 tahun $(94,3 \%)$, pendidikan dari ibu yang memiliki anak TB paru SMA merupakan yang paling tinggi jumlahnya yaitu $18(51,4 \%)$, dan responden memiliki pekerjaan yang terbesar adalah sebagai ibu rumah tangga yaitu $19(54,3 \%)$.

\section{Self-efficacy}

Berdasarkan hasil univariat self-efficacy ibu dengan anak yang sedang menjalani pengobatan tuberkulosis Di Ruang Poliklinik RS Mitra Plumbon Cirebon.tertera pada tabel berikut ini:

Tabel 2. Distribusi Responden Berdasarkan Self-efficacy

\begin{tabular}{lll}
\hline Self-efficacy & $\begin{array}{l}\text { Frekuens } \\
\text { i }\end{array}$ & Presentase (\%) \\
\hline Tinggi & 23 & 65,7 \\
Rendah & 12 & 34,3 \\
\hline Total & 35 & 100 \\
\hline
\end{tabular}

Berdasarkan tabel 2 menunjukan bahwa self-efficacy ibu yang memiliki anak dengan TB Paru yang sedang menjalani pengobatan di Rumah Sakit Mitra Plumbon Cirebon termasuk kategori baik dimana 23 responden berada pada kategori tinggi $(65,7 \%)$.

\section{PEMBAHASAN}

Penelitian ini dilihat dari karakteristik diperoleh usia ibu berada pada tahap awal antara 18-40 tahun berjumlah 33 (94,3\%). Selaras dengan penelitian Bandura yang menyatakan self-efficacy salah satu yang mempengaruhi adalah faktor umur, jika usianya lebih muda makan self-efficacy nya rendah, sedangkan pada penelitian ini usia responden adalah dewasa.

Pendidikan responden, jumlah terbanyak pendidikannya SMA $18(51,4$ \%). Hal inipun senada dengan pernyataan Bandura yang menyatakan bahwa Pendidikan yang cukup baik maka selfefficacy pun baik. Sedangkan dilihat dari 
JOURNAL OF NURSING PRACTICE AND EDUCATION VOL. 01 NO. 02, JUNI 2021

DOI: $10.34305 /$ JNPE.V1I2.301

pekerjaan hampir sebagian besar responden yaitu sebagai ibu rumah tangga sebanyak 19 responden $(54,3 \%)$.

Self-efficacy yang dialami pada ibu dengan anak TB Paru di Rumah Sakit Mitra Plumbon Cirebon tinggi sebanyak 23 responden $(65,7 \%)$.

\section{KESIMPULAN}

Berdasarkan karakteristik responden didapatkan Sebagian besar responden berusia dewasa awal (94,3\%), berpendidikan SMA berjumlah 18 atau $51,4 \%$, responden memiliki pekerjaan IRT yaitu $19(54,3)$. Sedangkan untuk self efficacy hasilnya adalah termasuk kategori baik atau tinggi 23 responden $(65,7 \%)$.

\section{SARAN}

Diharapkan dapat mengkaji lebih jauh lagi dukungan dan peran serta keluarga dengan anak TB Paru terutama dalam ketaatan minum obat. Hubungan terkait self efficacy ibu yang memiliki anak TB Paru khususnya dalam mengikuti program pengobatan $\mathrm{TB}$
Ciptaan disebarluaskan di bawah Lisensi Creative Commons Atribusi-NonKomersialBerbagiSerupa 4.0 Internasional.

yang rutin dalam jangka waktu Panjang.

\section{DAFTAR PUSTAKA}

Andi Purniawan. 2019. Faktor-Faktor Yang Mempengaruhi TB Anak Usia 0-14

Tahun. Purwokerto.

Bandura. 2009. "Cultivate Self-efficacy for Personal and Organizational Effectiveness." Handbook of Principles of Organization Behavior 2: 179-200.

Dinas Kesehatan Provinsi Jawa Barat. 2017. "Profil Kesehatan Dinas Kesehatan Provinsi Jawa Barat 2017.” Diskes Jabarprov, 52.

Donsu T. 2016. Metodologi Penelitian Perawat. Pustaka Baru. Yogyakarta. Fernadiyanti. Dhanang Puspita. Dary. 2018. Dukungan Keluarga Terhadap Pengobatan TB Paru Pada Anak Di Balai Kesehatan Masyarakat Ambarawa. Ambarawa Jawa tengah.

Kemenkes RI. 2016. Profil Kesehatan Indonesia. Kesehatan. Vol. 70. https://doi.org/10.1111/evo.12990.

Kementrian Kesehatan RI. 2014. "Basic Health Research 2013." Ministry of Health, Republic of Indonesia.

Nabilah, Ai Mardhiyah, Efri Widianti. 2016. Gambaran Self-efficacy Ibu Dengan Anak Yang Sedang Menjalani 
JOURNAL OF NURSING PRACTICE AND EDUCATION VOL. 01 NO. 02, JUNI 2021

DOI: $10.34305 /$ JNPE.V1I2.301
Ciptaan disebarluaskan di bawah Lisensi Creative Commons Atribusi-NonKomersialBerbagiSerupa 4.0 Internasional.

Pengobatan Tuberkulosis Di

Poliklinik Spesialis Anak RSUD

Cibabat Cimahi. Bandung.

Parlina. 2018. Gambaran Self Efficacy

Perawat Dalam Memberikan

Perawatan Pada Pasien TB Paru Di

Ruang Rawat Inap RSUD Dr.Slamet

Garut. Universitas Padjadjaran

Fakultas Keperawatan Bandu.

Putri. 2016. Pengantar Riset Keperawatan.

Pustaka Baru. Yogyakarta.

Sucipto D. 2020. Metodologi Penelitian

Kesehatan. Yogyakarta: Gosyen

Publishing. 